\title{
Assessment of Lake Orta sediments phytotoxicity after the liming treatment
}

\author{
Paola BARBERO, Monica BELTRAMI, Renato BAUDO* and Daria ROSSI \\ CNR Istituto Italiano di Idrobiologia, Largo V. Tonolli 50, 28922 Verbania Pallanza, Italy \\ *e-mail corresponding author: r.baudo@iii.to.cnr.it
}

\begin{abstract}
The paper presents results from seed germination and root elongation tests for the evaluation of Lake Orta sediment contamination. The protocol for this test was developed after a literature survey and careful investigation of the proper conditions for obtaining the germination of commercially available seeds of several plants. Cucumis sativus, Lactuca sativa, and Lepidium sativum were finally chosen and used to detect the phytotoxicity of both liquid and solid phases of Lake Orta sediments. To assess whether exchange at the water - sediment interface could represent a hazard for the environment and the actual bioavailability of the toxicants present into the sediments, the phytotoxicity of samples collected in 1992, 1994, 1996, 1997, and 1998 from selected stations was tested on seeds of three different plant species (Lactuca sativa, Lepidium sativum and Cucumis sativus). The obtained results allow drawing distribution maps of the germination index, which confirm the persistence of toxic effects. However, the lake seems to positively respond to the restoration treatment, since the more contaminated layers of sediments are presently buried under less toxic sediments.
\end{abstract}

Key words: phytotoxicity, L. Orta, sediments, Lactuca sativa, Lepidium sativum, Cucumis sativus

\section{INTRODUCTION}

Lake Orta has received industrial effluents containing high concentrations of copper and ammonia since 1926. Chromium-, nickel-, and zinc-rich effluents from plating factories have also contributed to pollution levels, and water column $\mathrm{pH}$ dropped below 4.0 because of the oxidation of ammonia to nitrates. As a remedial action, from May 1989 to June 1990, the lake was limed with 14,500 tons of $\mathrm{CaCO}_{3}$. The treatment was immediately effective in raising the $\mathrm{pH}$ and sedimenting the metals from the water column (Calderoni \& Tartari 2001).

To verify whether the actual conditions of Lake Orta sediments are still potentially dangerous for the biota, both pore water and whole sediments were used in a number of toxicity tests (Hyalella azteca, Ceriodaphnia dubia; Daphnia magna, D. obtusa; Microtox ${ }^{\mathrm{R}}$; Thamnotox; Rototox; and Seed Germination-Root Elongation). This paper will relate only the results of the latter tests, whereas the others are reported in other papers of this monograph (Baudo et al. 2001; Burton et al. 2001).

The seed germination and root elongation technique is an easy and inexpensive screening test. Many vascular plant species have seeds that can withstand long periods of drought. After rehydration, they face a series of rapid physiological changes (Bewley \& Black 1983). During this period, they are sensitive to environmental stress, which can influence early stages of development. Endpoints such as survival, germination, early stage growth, and later growth stages can easily be monitored. Since the metabolism, nutrient transport, and cell division of the seeds of several plants are greatly influenced by the medium conditions, phytotoxicity tests based on seed germination and root elongation to assess the potential contamination by metal ions or organic micropollutants have been proposed by government agencies as part of multi-trophic test batteries.

Suggested plant species include cucumber, lettuce, radish, red clover, and several varieties of wheat (Brusick \& Young 1981; Ratsch 1983; OECD 1984; Fletcher et al. 1985; Wang 1987a; Wang \& Williams 1988). Other candidate species include oats, corn, cabbage, carrots, soybeans, tomatoes, ryegrass, onions, and beans (U.S. Food and Drug Administration 1984; US EPA 1996), as well as rice, sorghum, mustard, rapeseed, turnip, vetch, fenugreek, and cress (OECD 1984). These techniques may be employed for both liquid (water, pore water) and solid (sediment) samples (Beltrami et al. 1999).

\section{MATERIAL AND METHODS}

Vascular plant seeds can be exposed while they are floating in a test solution, or they can be placed on filter paper soaked with the test solution (Ratsch \& Johndro 1986), thereby avoiding contact with the test soil or sediment (Dutka 1988). Seeds can also be deployed on a solid substrate and rehydrated with reference water or test solutions (OECD 1984; Thomas \& Cline 1985). Alternatively, they can be exposed to aqueous extracts from soils or sediments (Porcella 1983). In the present study, seed germination and root elongation have been tested on overlying water, pore water, and whole sediments.

In 1992 (Baudo et al. 1993) seven samples of Lake Orta sediments were collected by Ponar grab and an ad- 

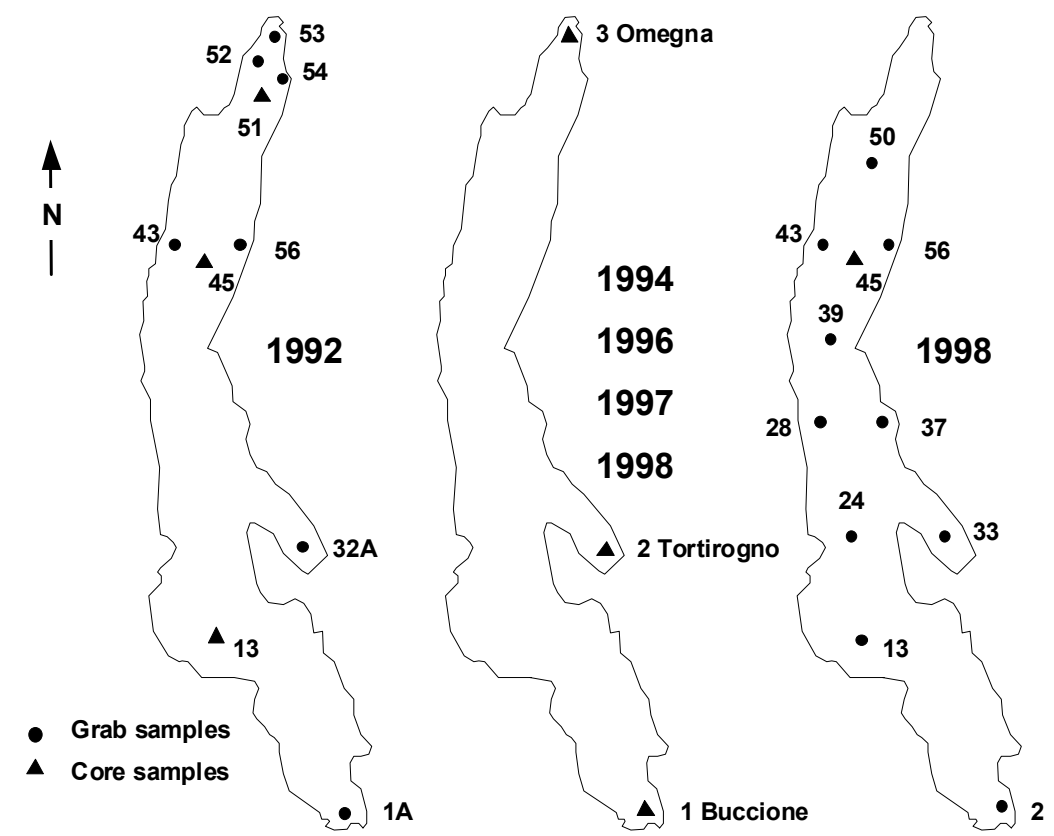

Fig. 1. Sampling points.

ditional three samples by means of a gravity corer (Fig. 1). Sediment cores were sectioned vertically in order to compare recently deposited sediments (from $0-10 \mathrm{~cm}$ ) with those deposited during peak periods of industrial discharge in the 1960s $(10-20 \mathrm{~cm})$, and also with deeper sediments from pre-industrial times $(20-30$ $\mathrm{cm})$.

Both grab samples and core sections were carefully homogenised and sub-sampled for both chemical analysis of pore water (obtained by centrifugation at 4500 rpm for $45 \mathrm{~min}$ in a centrifuge kept at $4{ }^{\circ} \mathrm{C}$, Baudo et al. 1993), and for toxicity tests.

For the seed germination and root elongation tests, seeds of the common lettuce (Lactuca sativa) were used, following the method described by Wang (1987a). For each experiment, $4 \mathrm{ml}$ of pore water were added to a polystyrene Petri dish $(60 \times 10 \mathrm{~mm})$ containing a Whatman No. 1 ashless filter paper disk. Ten seeds were placed on each filter, with 4 replicates for each pore water sample. Controls with deionised water (4 replicates each) were tested concurrently. The plates were incubated at $20^{\circ} \mathrm{C}$ in the dark for 96 hours, then the germinated seeds were counted and the root length measured by means of a ruler to the closest millimetre.

Two different end points were quantified in order to evaluate the effect of the pore waters on plant physiological processes: seed germination and root elongation. In order to provide an integrative interpretation, seed germination and root elongation can be combined into an Index of Germination (IG \%), according to the equation:

$$
\mathrm{IG} \%=(\mathrm{Gs} \mathrm{Ls}) /(\mathrm{Gc} \mathrm{Lc}) \times 100
$$

where Gs and Ls are the seed germination and root elongation (mm) for the sample; Gc and Lc the corresponding values for controls.

Following a different approach, in November 1994, duplicate sediment cores and overlying water samples were collected by SCUBA at a depth of $10 \mathrm{~m}$ at three stations in Lake Orta (St. 1 Buccione; St. 2 Tortirogno, St. 3 Omegna). These locations were carefully selected to reflect the spatial variability of sediment contamination (Baudo et al. 1997).

Sampling was repeated in June and November 1996 at two stations only (station 3 was discarded for logistic reasons), and again in 1997 and in 1998.

Cores were prepared for analysis by siphoning off the overlying water, and then sectioning sediment into 2 $\mathrm{cm}$ layers and drying each sample at $60{ }^{\circ} \mathrm{C}$. Both overlying water and wet sediments were then used for phytotoxicity testing with three different plant species. These tests were set with either either $5 \mathrm{ml}$ of overlying water, or $10 \mathrm{~g}$ wet sediment $+5 \mathrm{ml}$ deionised water in polystyrene Petri dishes $(\varnothing 100 \mathrm{~mm})$. Whatman No. 1 ashless filter paper disks were placed over each sample, then seeded with 10 seeds in each of 4 replicate dishes. After 3 days in the dark at $25^{\circ} \mathrm{C}$, the germinated seeds were counted and the root length measured by means of a ruler. Controls (4 replicates), in which seeds were treated with deionised water only, were also prepared.

Results were evaluated with respect to control charts based on tests with two reference toxicants, $\mathrm{K}_{2} \mathrm{Cr}_{2} \mathrm{O}_{7}$ and $\mathrm{Cu}\left(\mathrm{NO}_{3}\right)_{2}$, as suggested by Wang (1987a). These positive controls were considered appropriate because of the very high concentrations of chromium and copper in Lake Orta sediments (Baudo \& Beltrami 2000). As 
expected, the tests with the reference toxicants demonstrated that sensitivity varies among seed species (Tab. 1; Baudo et al. 1999). Therefore, for all subsequent tests, seeds of Lactuca sativa, Cucumis sativus, and Lepidium sativum were used.

Tab. 1. EC 50 values for $\mathrm{Cr}$ and $\mathrm{Cu}\left(\mathrm{mg} \mathrm{l}^{-1}\right)$ and $95 \%$ confidence interval (C.I.).

\begin{tabular}{lcccc}
\hline & EC50 Cr & $95 \%$ C.I. & EC50 Cu & 95\% C.I. \\
\hline Lepidium sativum & 4.14 & $3.47-4.94$ & 1.21 & $1.13-1.30$ \\
Lactuca sativa & 6.42 & $4.12-9.98$ & 0.95 & $0.29-3.14$ \\
Cucumis sativus & 43.58 & $38.7-50.02$ & 4.80 & $4.23-5.44$
\end{tabular}

In March 1998, samples of sediments were again taken by Ponar grab at 10 selected stations, and 3 Jenkins gravity core samples at the deepest point of Lake Orta (143 m; St. 45). The samples were then processed as previously described, and used for toxicity testing with seeds of Lactuca sativa, Cucumis sativus, and Lepidium sativum. For the 1992 and 1998 grab samples, the results have been used to draw phytotoxicity maps, using the Surfer 6 software.

\section{RESULTS AND DISCUSSION}

\subsection{2}

In 1992, the germination rates of Lactuca sativa seeds in the controls ranged from 92.5 to $97.5 \%$, with an average of $95 \%$. The only sample showing a germination rate significantly lower than the control was the core segment from 10-20 cm taken at Station 51. This result can be explained by the fact that this site contains the peak level of pollution (with concentrations in pore water of $120 \mathrm{\mu g}^{-1}$ copper, $20 \mu \mathrm{g} \mathrm{l}^{-1}$ chromium, and 6.14 $\mathrm{mg}^{-1}$ ammonium nitrogen; Baudo et al. 1996).

Root elongation values for 3 control experiments showed excellent repeatability, with means of 33.2, 34.4 and $34.8 \mathrm{~mm}$ in the three experiments, with coefficient of variation $(\% \mathrm{CV})$ of $18.6 \%, 34.3 \%$ and $15.7 \%$, respectively. In the fifteen assays with pore water samples, \% CV ranged from $13.7 \%$ to $40.6 \%$, with an average value of $26.6 \%$. The most interesting finding is that many pore samples, both from grabs and core sections, appeared to stimulate growth, relative to the controls (Fig. 2). This phenomenon, known as hormesis (Stebbing 1982), may be due to a growth promotion factor which is absent in the deionised water used for the controls; or it may represent the first sign of toxicity, with seeds growing faster to dilute toxicants in a larger mass.

The only significant inhibition of root elongation (Student-Newman Keuls test, $\mathrm{p} \leq 0.05$ ) was produced by the pore water from station 43. Analysis of sediment from this station showed elevated levels of polychlorinated biphenyls (PCB, $70 \mu \mathrm{g} \mathrm{kg}^{-1}$ ), DDT and metabolites $\left(120 \mu \mathrm{g} \mathrm{kg}^{-1}\right)$, and lindane and metabolites $(25 \mu \mathrm{g}$ $\mathrm{kg}^{-1}$ ). Station 43 was the only station sampled with measurable levels of all of these three classes of organic compounds (Guzzella et al. 1993).
Nevertheless, a stepwise multiple regression analysis yielded an equation with seven chemical variables which explained $96.3 \%$ of the variance in root elongation (Baudo 1994b). In fact, the regression relationship probably represents a response composed of stimulation by $\mathrm{Mn}, \mathrm{Na}, \mathrm{Cu}, \mathrm{Cl}$ and $\mathrm{N}-\mathrm{NO}_{3}$ and inhibition by $\mathrm{Mg}$ and Cr.

$$
\mathrm{E}=32.98-0.44[\mathrm{Mg}]_{\mathrm{sed}}+0.63[\mathrm{Mn}]_{\mathrm{sed}}+0.54[\mathrm{Na}]_{\mathrm{pw}}+
$$$$
0.72[\mathrm{Cu}]_{\mathrm{pw}}-0.71[\mathrm{Cr}]_{\mathrm{pw}}+0.71[\mathrm{Cl}]_{\mathrm{pw}}+0.29\left[\mathrm{~N}-\mathrm{NO}_{3}\right]_{\mathrm{pw}}
$$

Where, $\mathrm{E}=$ root elongation $(\mathrm{mm}),[] \mathrm{sed}=$ concentration in sediment $\left(\mathrm{mg} \mathrm{kg}^{-1}\right)$ and [ ]pw = concentration in pore water $\left(\mathrm{mg} \mathrm{l}^{-1}\right)$.

As an exploratory experiment, seeds of Lactuca sativa were also exposed to whole sediments from the surficial core stratum $(0-10 \mathrm{~cm})$ at station 51 . An IG \% of 82 was found, as compared with an IG \% of 108 obtained for pore water. These results indicate that testing of whole sediments rather than pore water could yield additional sensitivity.

\section{2. $1995-1998$}

Tests on overlying water, siphoned off from the top of cores, indicated that in the whole period the germination index (Tab. 2 ) was initially (1994) lower than controls, but progressively increased, suggesting that the biostimulation (hormesis) phenomena became prevalent. However, these results do not prove conclusively that the sediment conditions are improving, since the tests were done in different seasonal periods and differences in temperature could have affected the diffusion of pollutants from sediments to overlying water.

After 1997 the phytotoxicity tests were also performed on $2 \mathrm{~cm}$ vertical sections of the sediments cores, and these tests revealed a much more pronounced effect on the seed germination and root elongation of all three species. For these tests, the results for overlying water present a statistically significant $(\mathrm{P}<0.05)$ negative exponential regression with the mean IG \% for the cores $\left(\mathrm{R}^{2}=0.3259\right)$, and another one, slightly better $\left(\mathrm{R}^{2}=\right.$ $0.3755)$, with IG \% for the first section $(0-2 \mathrm{~cm})$. These results indicate that an increase in the inhibition observed in sediment samples (IG \% values $<100 \%$ ), corresponds an increase in the biostimulation (IG \% $>100 \%$ ) for overlying water samples.

These relationships suggest that, due to the pollutant diffusion from sediment to water, sediments richer in toxics induce a greater hormetic response in overlying water, thus supporting the hypothesis that biostimulation represents the first sign of a disturbance for seed germination and root elongation. This is then followed by true inhibition when the toxicants reach even higher concentrations in overlying water.

The results obtained in different years for the sediment samples are fairly consistent among each other, and can be summarised as follows: 


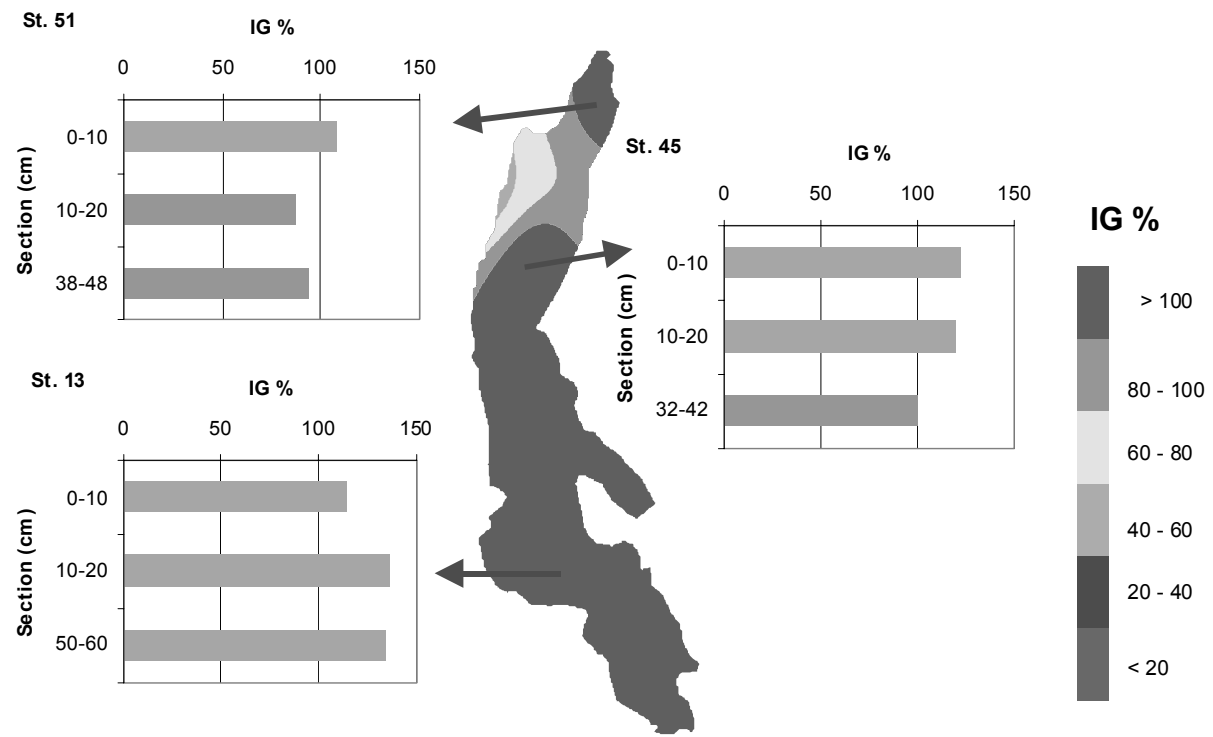

Fig. 2. Map of distribution of the Index of Germination (\% of control) for Lactuca sativa seeds tested on Lake Orta 1992 pore water.

Tab. 2. IG \% for overlying water.

\begin{tabular}{|c|c|c|c|c|c|c|c|c|}
\hline \multirow[b]{2}{*}{ Date } & \multicolumn{3}{|c|}{ Cucumis sativus } & \multicolumn{3}{|c|}{ Lepidium sativum } & \multicolumn{2}{|c|}{ Lactuca sativa } \\
\hline & Buccione & Tortirogno & Omegna & Buccione & Tortirogno & Omegna & Buccione & Tortirogno \\
\hline Oct. 94 & 87.6 & 71.6 & 100.3 & 84.6 & 79.8 & 85.3 & & \\
\hline Nov. 95 & 84.5 & & & & & & 103.5 & \\
\hline Jun. 96 & 82.4 & 80.0 & & 111.5 & 115.5 & & 117.6 & 120.2 \\
\hline Nov. 96 & 95.6 & 77.1 & & 112.3 & 124.0 & & 129.5 & 101.2 \\
\hline Jul. 97 & 121.4 & 103.3 & & 101.6 & 94.8 & & 114.4 & 115.5 \\
\hline
\end{tabular}

- Cucumis sativus (Fig. 3) is the less sensitive species, Lepidium sativum (Fig. 4) the most sensitive, and Lactuca sativa (Fig. 5) shows intermediate responses;

- tests on wet sediments always resulted in a more pronounced toxicity than tests on overlying water from the same core;

- core top layers are generally less toxic than intermediate sections (Tab. 3);

- even at the bottom of these short cores, the germination index shows either biostimulation or inhibition;

- among stations, the toxicity on the whole cores ranks: Tortirogno $<$ Buccione $<<$ St. 45 .

These results agree with available information about metal distribution in Lake Orta and its past history of contamination (Baudo \& Beltrami 2000), indicating that toxicants tend to be concentrated in the deepest part of the lake (corresponding to St. 45). Results also correspond to concentration peaks for metals like $\mathrm{Cu}$ and $\mathrm{Cr}$ at a depth between 4 to $10 \mathrm{~cm}$ in the bottom sediments.

\subsection{8}

Results obtained in 1998 have been used to draw maps of distribution of the germination index for $\mathrm{Cucu}$ - mis sativus, Lepidium sativus and Lactuca sativa (Fig. $6)$.

With the usual difference in sensitivity, the three seed species show a marked reduction of the germination index in the northern end of the lake. Moreover, both Lepidium sativum and Lactuca sativa display a remarkable inhibition in the central part, and L. sativa also in correspondence with the inlet of River Lagna, known to carry a heavy load of metals, especially $\mathrm{Cu}$ and $\mathrm{Cr}$, as a result of the discharge of effluents from plating factories.

The phytotoxicity tests are in good agreement with the known distribution of metals in Lake Orta sediments (Baudo \& Beltrami 2000). Areas producing biostimulation and/or inhibition typically correspond to areas of metal accumulation.

However, the statistical analysis failed to detect significant correlations between germination indexes and major, minor and trace elements in sediments. In fact, seeds appeared to respond to the chemical composition as a whole, rather than to single toxicants.

On the other hand, the multiple regressions between IG \% and all investigated elements $(\mathrm{Si}, \mathrm{Al}, \mathrm{Fe}, \mathrm{Ti}, \mathrm{Ca}$, $\mathrm{K}, \mathrm{Mg}, \mathrm{Na}, \mathrm{P}, \mathrm{S}, \mathrm{Pb}, \mathrm{Zn}, \mathrm{Cu}, \mathrm{Ni}, \mathrm{Mn}, \mathrm{Cr}, \mathrm{C}, \mathrm{N})$ produced the following equations: 


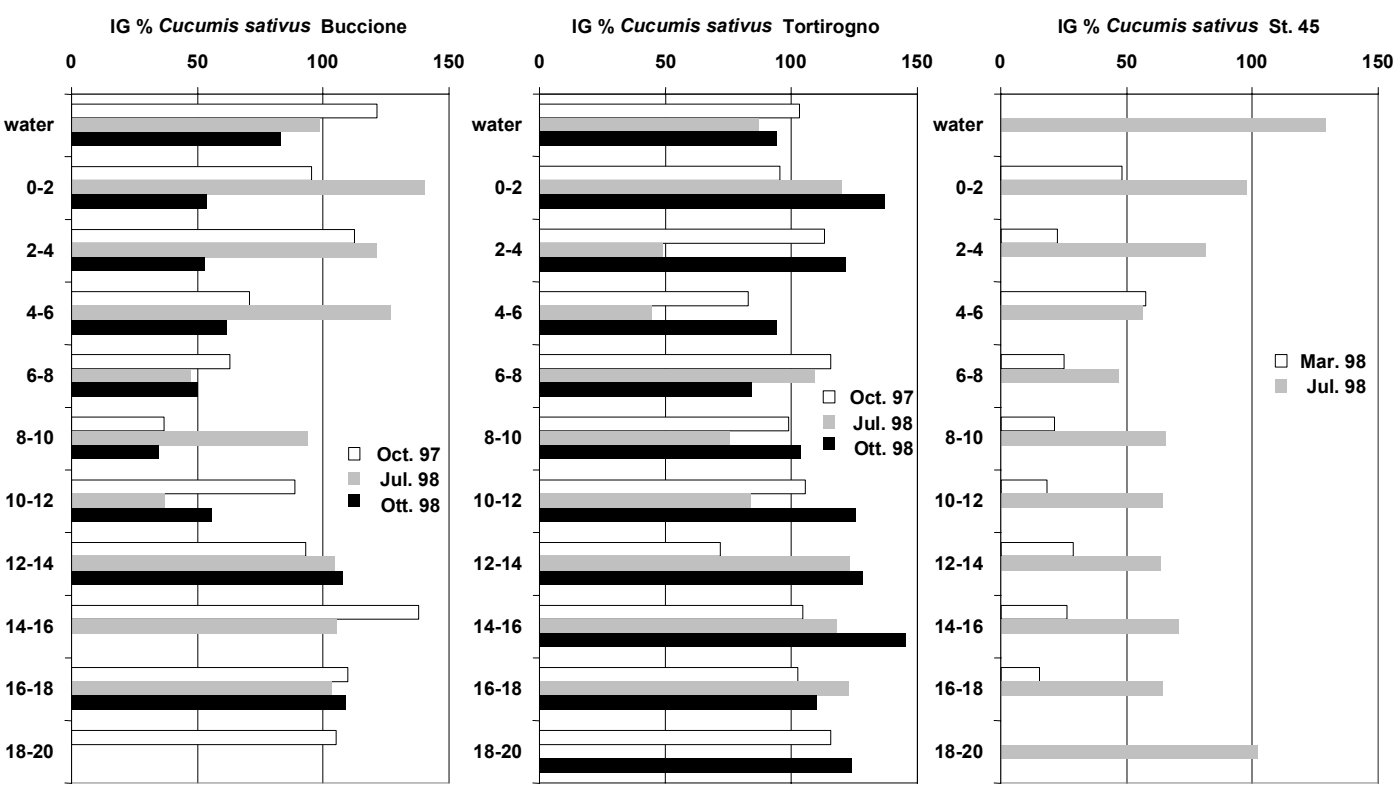

Fig. 3. IG \% for Cucumis sativus along cores (in $2 \mathrm{~cm}$ sections) from 3 stations (water = overlying water).
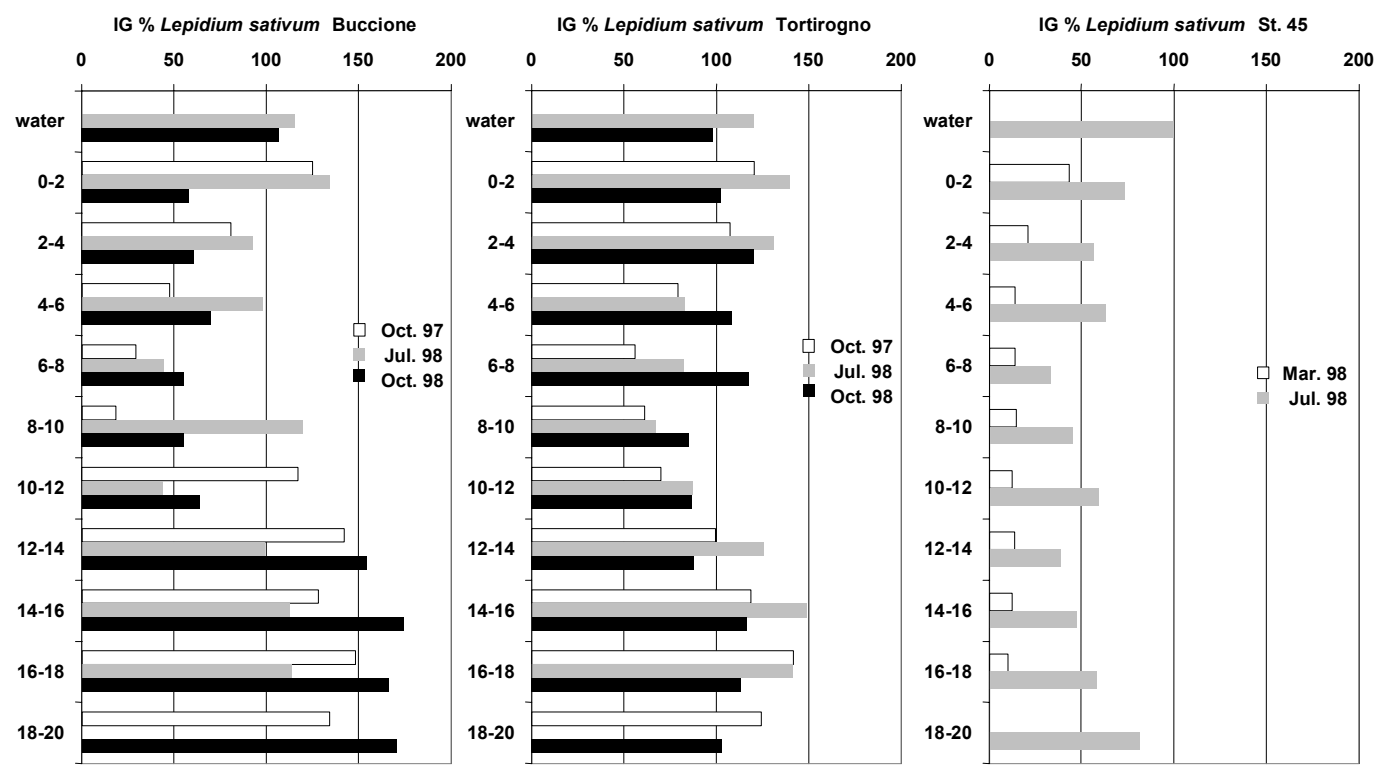

Fig. 4. IG \% for Lepidium sativum along cores (in $2 \mathrm{~cm}$ sections) from 3 stations (water = overlying water).

Tab. 3. IG $\%$ mean values $(\mathrm{B}=$ Buccione; $\mathrm{T}=$ Tortirogno $)$.

\begin{tabular}{|c|c|c|c|c|c|c|c|c|c|}
\hline & \multicolumn{3}{|c|}{ Cucumis sativus } & \multicolumn{3}{|c|}{ Lepidium sativum } & \multicolumn{3}{|c|}{ Lactuca sativa } \\
\hline & B & $\mathrm{T}$ & St. 45 & B & $\mathrm{T}$ & St. 45 & B & $\mathrm{T}$ & St. 45 \\
\hline Overlying water & 101 & 95 & 129 & 111 & 109 & 100 & 93 & 112 & 135 \\
\hline $0-2$ & 96 & 117 & 73 & 105 & 120 & 58 & 106 & 100 & 45 \\
\hline $2-4$ & 96 & 95 & 52 & 78 & 119 & 39 & 35 & 120 & 37 \\
\hline $4-6$ & 87 & 74 & 57 & 72 & 90 & 38 & 36 & 73 & 2 \\
\hline $6-8$ & 53 & 103 & 36 & 43 & 85 & 24 & 25 & 71 & 6 \\
\hline $8-10$ & 55 & 93 & 43 & 64 & 71 & 30 & 75 & 59 & 9 \\
\hline $10-12$ & 60 & 105 & 41 & 75 & 81 & 36 & 56 & 101 & 6 \\
\hline $12-14$ & 102 & 108 & 46 & 132 & 104 & 26 & 129 & 112 & 6 \\
\hline $14-16$ & 122 & 123 & 49 & 138 & 128 & 30 & 100 & 125 & 6 \\
\hline $16-18$ & 107 & 112 & 40 & 143 & 132 & 34 & 105 & 111 & 9 \\
\hline $18-20$ & 105 & 120 & 102 & 152 & 113 & 81 & & 87 & 15 \\
\hline
\end{tabular}




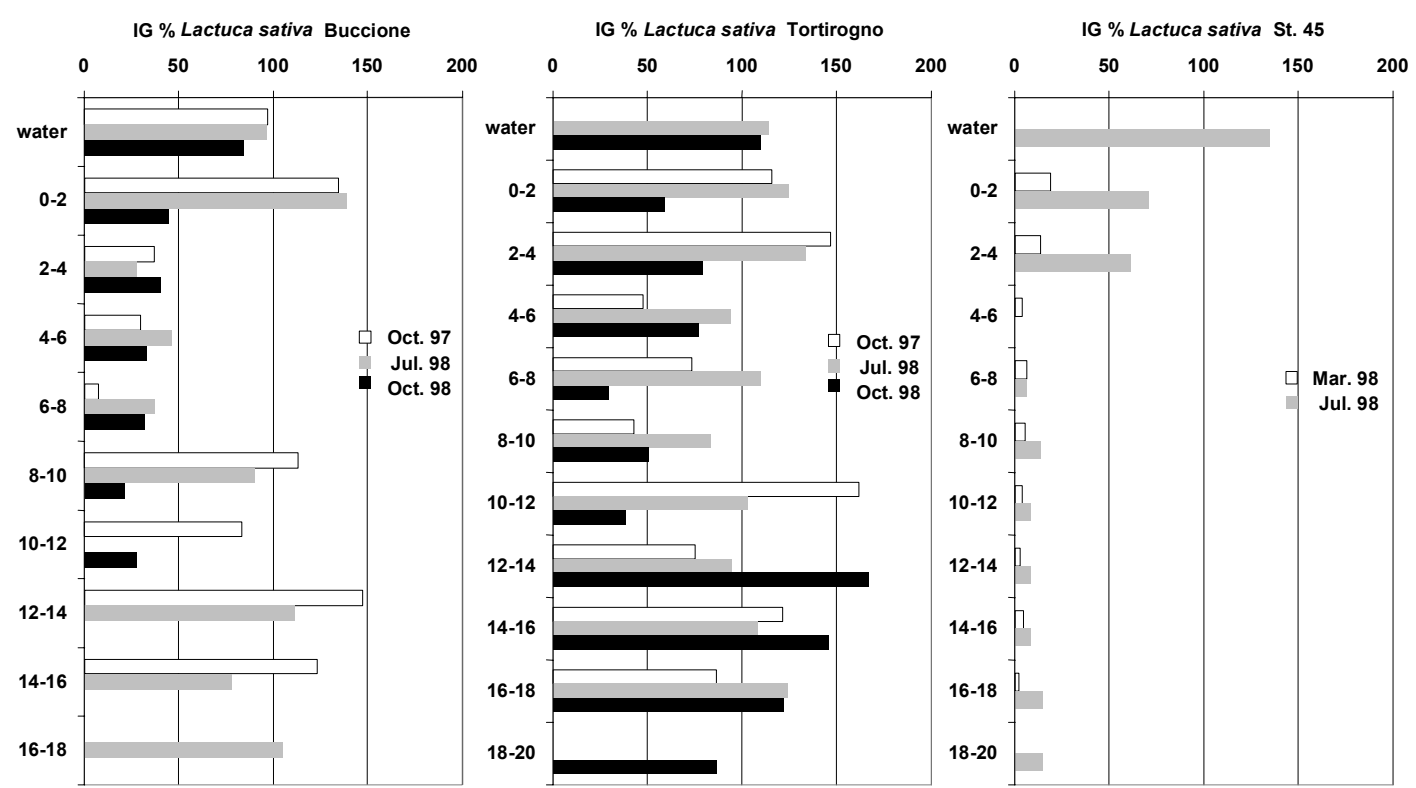

Fig. 5. IG \% for Lactuca sativa along cores (in $2 \mathrm{~cm}$ sections) from 3 stations (water $=$ overlying water).
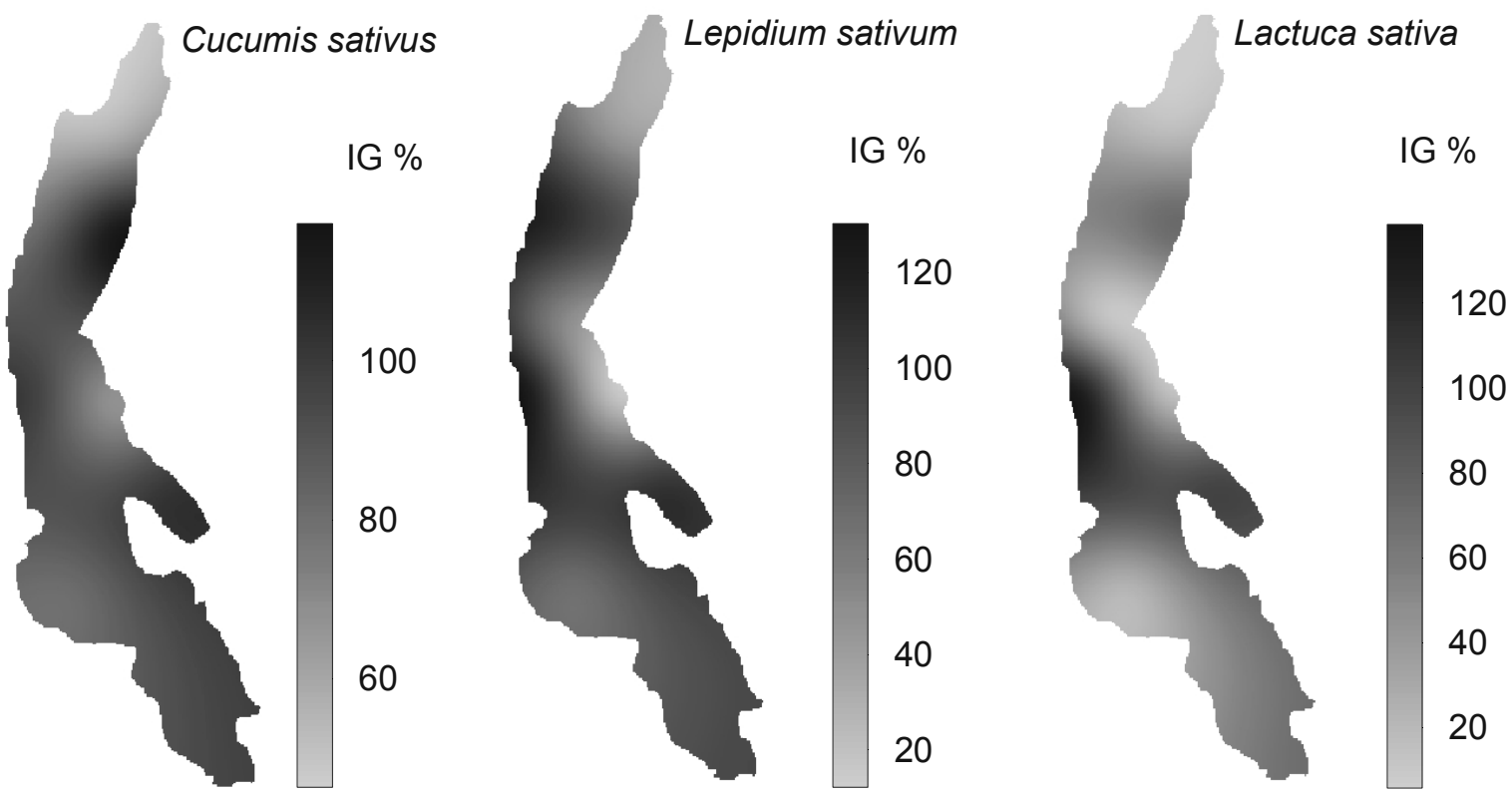

Fig. 6. Maps of distribution of IG \% for the three seed species (1998 sampling).

IG Cucumis $=17.5-0.12[\mathrm{Si}]+0.001[\mathrm{Zn}]-0.004$

$[\mathrm{Pb}]-7.78[\mathrm{Ti}]-0.408[\mathrm{Mg}]+0.00007[\mathrm{Mn}]-0.05$

[Al]

$(\mathrm{R}=0.9999 ; \mathrm{P}=0.00005)$

$\mathrm{IG}$ Lepidium $=14.6-0.005[\mathrm{~Pb}]-0.45[\mathrm{Al}]+0.0006$

$[\mathrm{Cr}]-0.0055[\mathrm{Ni}]$

$(\mathrm{R}=0.9230 ; \mathrm{P}=0.005)$

IG Lactuca $=1.82-0.04$ Depth $+21.3[$ Ti $]-0.004[\mathrm{Cr}]$ $(\mathrm{R}=0.7377 ; \mathrm{P}=0.17)$
The least significant multiple regression, the one for Lactuca sativa, explains $54 \%$ of the observed variability, whereas for Lepidium sativum the explained fraction increases to $96 \%$, and to $99.99 \%$ for Cucumis sativus.

Therefore, according to this statistical analysis, seed germination and root elongation depends on the sediment matrix composition $(\mathrm{Si}, \mathrm{Ti}, \mathrm{Mg}, \mathrm{Mn}, \mathrm{Al}$ in $\mathrm{Cucu}$ mis; $\mathrm{Al}$ in Lepidium; Ti in Lactuca). This is likely because the presence of major elements controls the bioavailability of toxic metals ( $\mathrm{Pb}$ and $\mathrm{Zn}$ for Cucumis; $\mathrm{Pb}$, $\mathrm{Cr}$ and $\mathrm{Ni}$ for Lepidium; $\mathrm{Cr}$ again for Lactuca). 


\section{CONCLUSIONS}

The liming of Lake Orta successfully sedimented a great part of metals residing in the water column, as demonstrated by the comparison between the 1985 and 1996 samplings (Tab. 4; Baudo et al. 1997). Therefore, it is not surprising that the top layers of sediment affect the seed germination and root elongation of Lactuca sativa, Lepidium sativum and Cucumis sativus.
In time, with the sedimentation of less contaminated or uncontaminated particulate matter, the toxic layer will be buried deep enough to lower or stop the backdiffusion of pollutants, thus restoring safe conditions at the sediment - water interface. However, since the sedimentation rate in Lake Orta is relatively low at a few millimetres per years, these will take some time. In order to better understand the processes involved in the

Tab. 4. Comparison of the mean chemical composition of Lake Orta sediments in 1985 and 1996 (Baudo et al. 1997).

\begin{tabular}{|c|c|c|c|c|c|c|c|}
\hline & \multicolumn{3}{|c|}{1985} & \multicolumn{3}{|c|}{1996} & \multirow{2}{*}{$\begin{array}{c}\text { Variation } \\
(\%)\end{array}$} \\
\hline & Mean & $\min$ & Max & Mean & $\min$ & Max & \\
\hline Total C (\%) & 3.87 & 0.05 & 9.26 & 7.72 & 0.19 & 15.52 & 49.9 \\
\hline Organic C $(\%)$ & 3.55 & 0.04 & 8.89 & & & & \\
\hline $\mathrm{N}(\%)$ & 0.33 & 0.01 & 0.88 & 0.73 & 0.12 & 1.32 & 54.3 \\
\hline $\mathrm{Si}(\%)$ & 28.9 & 24.2 & 31.9 & 25.5 & 20.1 & 31.3 & -13.3 \\
\hline $\mathrm{Al}(\%)$ & 8.58 & 5.46 & 11.03 & 8.53 & 6.46 & 10.22 & -0.5 \\
\hline $\mathrm{Fe}(\%)$ & 4.55 & 0.68 & 9.13 & 5.51 & 2.83 & 8.95 & 17.5 \\
\hline Ti (\%) & 0.39 & 0.02 & 0.61 & 0.44 & 0.27 & 0.61 & 11.8 \\
\hline $\mathrm{Ca}(\%)$ & 0.61 & 0.18 & 1.40 & 0.82 & 0.43 & 1.61 & 25.3 \\
\hline K (\%) & 2.17 & 1.02 & 4.28 & 2.00 & 1.41 & 3.11 & -8.6 \\
\hline $\operatorname{Mg}(\%)$ & 1.01 & 0.65 & 2.42 & 0.99 & 0.63 & 1.99 & -2.1 \\
\hline $\mathrm{Na}(\%)$ & & & & 1.05 & 0.67 & 2.23 & \\
\hline P (\%) & 0.13 & 0.05 & 0.24 & 0.20 & 0.07 & 0.29 & 32.7 \\
\hline S (\%) & 0.18 & 0.01 & 1.20 & 0.56 & 0.07 & 1.79 & 67.2 \\
\hline $\mathrm{Pb}\left(\mathrm{mg} \mathrm{kg}^{-1}\right)$ & 127 & 5 & 542 & 305 & 24 & 660 & 58.5 \\
\hline $\mathrm{Zn}\left(\mathrm{mg} \mathrm{kg}^{-1}\right)$ & 212 & 58 & 807 & 381 & 134 & 1004 & 44.3 \\
\hline $\mathrm{Cu}\left(\mathrm{mg} \mathrm{kg}^{-1}\right)$ & 480 & 14 & 1664 & 997 & 72 & 2440 & 51.8 \\
\hline $\mathrm{Ni}\left(\mathrm{mg} \mathrm{kg}^{-1}\right)$ & 59 & 16 & 165 & 104 & 30 & 303 & 43.5 \\
\hline $\operatorname{Mn}\left(\mathrm{mg} \mathrm{kg}^{-1}\right)$ & 641 & 149 & 6802 & 570 & 259 & 1767 & -12.5 \\
\hline $\mathrm{Cr}\left(\mathrm{mg} \mathrm{kg}^{-1}\right)$ & 339 & 9 & 1304 & 825 & 136 & 2877 & 58.8 \\
\hline
\end{tabular}

From tests on sediment cores it appears that the toxicity of recent sediments is reduced in comparison with deeper layers. These deeper sediment samples correspond to material deposited in the past, when the metal pollution of the lake was greater.

The reduction in toxicity may be due to a diminished bioavailability of metals like $\mathrm{Cu}$ and $\mathrm{Cr}$. Recent sediments are enriched in organic substance (as indicated by the increase in carbon and nitrogen), and all trace elements $(\mathrm{Pb}, \mathrm{Zn}, \mathrm{Cu}, \mathrm{Ni}, \mathrm{Mn}, \mathrm{Cr})$ are statistically correlated to $\mathrm{N}$ and $\mathrm{C}$ concentrations. This suggests that the release of toxic metals into the water column is prevented, or diminished, by the binding to organic matters. This hypothesis could explain why the toxicity of overlying water is always lower than for sediment from the same core.

However, 8 years after the liming treatment, Lake Orta sediment remains moderately toxic, as demonstrated in the present plant study and by tests with other organisms (e.g. Rossi \& Beltrami 1998; Rossi et al. 1998; Burton et al. 2000; Baudo et al. 2000).

Furthermore, as suggested by some preliminary results (Guzzella et al. 1993), Lake Orta sediments may also be contaminated by organic micropollutants, which may contribute to the overall toxicity of the samples. recovery of this large lake, continued monitoring of the actual toxicity of Lake Orta sediments and the recovery of the lake will be necessary in the coming years.

\section{REFERENCES}

Baudo, R., G.A. Tartari, A. Lami, P. Ross, F. Bo, R. Cenci, R. Vivian \& H. Muntau. 1993. Ecological risk of in-situ contaminants in Lake Orta. 14th Annual Meeting SETAC Ecological Risk Assessment: Lessons Learned? Houston, TX, USA, 14-18 November 1993. Abstract Book: 141.

Baudo, R., P. Ross \& L. Guzzella. 1996. Liming as a remedial action for an industrially polluted lake (Lake Orta, Northern Italy). In: M. Munawar \& G. Dave (Eds), Development and Progress in Sediment Quality Assessment: Rationale, Challenges, Techniques \& Strategies. Ecovision World Monograph Series, SPB Academic Publishing, Amsterdam: 177-193.

Baudo, R., M. Beltrami \& D. Rossi. 1997. The successful recovery of an impacted lake (Lake Orta, Italy). Proc. 3rd Conference on geochemistry, September 3-4, 1997, Alexandria, Egypt: Vol. II, Geochemistry of Sedimentary Rocks: 203-227.

Baudo, R., M. Beltrami, P. Barbero \& D. Rossi. 1999. Test di germinazione e allungamento radicale. Acqua Aria, 2/99: 69-85.

Baudo, R. \& M. Beltrami. 2001. Chemical composition of Lake Orta sediments. J. Limnol., 60(2): 213-236.

Baudo, R., D. Rossi \& M. Beltrami. 2001. In situ toxicity testing of Lake Orta sediments. J. Limnol., 60(2): 277-284. 
Beltrami, M., D. Rossi \& R. Baudo. 1999. Phytoxicity assessment of Lake Orta sediments. Aquatic Ecosystem Health \& Management, 2: 391-401.

Bewley, J.D. \& M. Black. 1983. Physiology and Biochemistry of Seeds in Relation to Germination. 1. Development Germination and Growth. Springer - Verlag: 306 pp.

Brusick, D.J. \& R.R. Young. 1981. IERL-RTP procedure manual: level 1, environmental assessment biological tests. US Environmental Protection Agency, Washington, D.C.: EPA-600/8-81-024.

Burton, G.A., Jr., R. Baudo, M. Beltrami \& C. Rowland. 2001. Assessing sediment contamination using six toxicity assays. J. Limnol., 60(2): 263-267.

Buysman, E., J.F.M. Maas \& W.H.M. Asman. 1985. Ammonia emission in Europe. Inst. Meteorology and Oceanography, Sate Univ. Utrecht, The Netherlands. Report R-85-2: 28 pp.

Calderoni, A. \& G.A. Tartari.. 2001. Evolution of the water chemistry of Lake Orta after liming. J. Limnol., 60(1): 6978 .

Dutka, B.J. (Ed.). 1988. Methods for microbiological and toxicological analysis of waters, wastewaters and sediments. Short term root elongation toxicity bioassay (Tentative). National Water Research Institute, Burlington, Canada: VIII/120- VIII/122.

Fletcher, J.S., M.J. Muhitch, D.R. Vann, J.C. McFarlane \& F.E. Benenati. 1985. Review: PHYTOTOX database evaluation of surrogate plant species recommended by the U.S. Environmental Protection Agency and the Organization for the Economic Cooperation and Development. Environ. Toxicol. Chem., 4: 523-532.

Guzzella, L., P. Ross, C. Bartone \& R. Baudo. 1993. Toxicity identification evaluation of Lake Orta sediments. I SETAC World Congr. "Ecotoxicology and Environmental Chemistry - a Global Perspective. Lisbon, Portugal, March 2831, 1993. Abstract Book: abstr. 108.

OECD. Organization for the Economic Cooperation and Development. 1984. Terrestrial plants: Growth test. OECD Guidelines for testing of chemicals, Paris: No. 208.
Porcella, D.B. 1983. Protocol for bioassessment of hazardous waste sites. U.S. Environmental Protection Agency, Corvallis, OR. EPA 600/2-83-054.

Ratsch, H.C. 1983. Interlaboratory Root Elongation Testing of Toxic Substances on Selected Plant Species. U.S. Environmental Protection Agency, Corvallis Environmental Research Laboratory, Corvallis, OR. EPA-600/3-85-051.

Ratsch, H.C. \& D. Johndro. 1986. Comparative toxicity of six test chemicals to lettuce using two root elongation test methods. Environ. Monit. Assess., 6: 267-276.

Rossi, D. \& M. Beltrami. 1998. Sediment ecological risk assessment: in situ and laboratory toxicity testing of Lake Orta sediments. Chemosphere, 37: 2885-2894.

Rossi, D., R. Baudo, M. Beltrami, M. Contesini e A. Pranzo. 1998. Valutazione della tossicità dei sedimenti del Lago d'Orta mediante esposizione di organismi in situ e test di laboratorio. Acqua Aria, 98/6: 105-114.

Stebbing, A.R.D. 1982. Hormesis - the stimulation of growth by low levels of inhibitors. Sci. Total Environ., 22: 213234.

Thomas, J.M. \& J.F. Cline. 1985. Modification of the Neubauer technique to assess toxicity of hazardous chemicals in soils. Environ. Toxicol. Chem., 4: 201-207.

U.S. EPA. 1996. Ecological Effects Test Guidelines. OPPTS 850.4200. Seed Germination/Root Elongation Toxicity Test. EPA 712-C-96-154. April 1996.

U.S. Food \& Drug Administration. 1984. Seed germination. Environmental assessment technical guide No. 11.06 (Draft). Center for Food Safety and Applied Nutrition, Center for Veterinary Medicine, U.S. Department of Health and Human Services, Washington, D.C.

Wang, W. 1987a. Chromate ion as a reference toxicant in aquatic phytotoxicity tests. Environ. Toxicol. Chem., 6: 953-960.

Wang, W. 1987b. Root elongation method for toxicity testing of organic and inorganic pollutants. Environ. Toxicol. Chem., 6: 409-414.

Wang, W. \& J.M. Williams. 1988. Screening and biomonitoring of industrial effluents using phytotoxicity tests. Environ. Toxicol. Chem., 7: 645-652. 